\title{
Die lyf se troos
}

\author{
J H le Roux \\ (Universiteit van Pretoria)
}

\section{ABSTRACT}

\section{The body's comfort}

This article focuses on the body as an 'instrument' to console and comfort others. In the early church so much attention was given to the soul and its salvation that the body was neglected. According to the Manichaeans the soul was related to God and separated from the body. The body on the other hand was so despicable that sensual pleasures could not even defile it more. Augustine integrated soul and body and allowed for sexual enjoyment in marriage but viewed the desire negatively. The rest of the article stresses the point that in times of distress the body of the other can console and relieve one from much stress. Especially in misery and in the daily experience of life's meaningless the advice of Ecclesiastes to enjoy 'life with the wife whom you love' (9:9) is taken seriously.

Die lewe is een lang sug na die ander. $\mathrm{Na}$ die ander se voelbare nabyheid en lyflike troos. Dit was van die begin af so en sal altyd so bly. Selfs God het dit gou na die mens se skepping al besef. Elke dag het die mens in die tuin gewerkskaf en dit versorg, maar iets het nog kortgekom. Hy was alleen en kon nie op sy eentjie regkom nie. Hy het na iemand gehunker en God het dit raakgesien. So erg was dié eensaamheid dat God selfs gesê het dit is 'nie goed ... dat die mens alleen is nie' (Gen 2:18).

In die loop van die eeue is egter verskillend oor hierdie ander persoon gedink. Soms was hy/sy meer en soms minder konkreet. In hierdie artikel val die soeklig meer op die konkrete lyf wat genot ervaar en ander gelukkig maak. In die Ou Testament was alles ook meer konkreet-lyflik: die mens is nie in onderdele (soos siel en liggaam) verdeel nie, maar het as totale mens ander liggame ervaar. God het ook met die totale mens gewerk en nie net die siel gered nie. Te midde van die Hellenistiese wêreld en die 'Platonisering' van die Christelike geloof het die vroeë kerk egter anders oor die liggaam en seks gedink. Hieronder word dié punt aan die hand van Augustinus en die Manicheërs geïllustreer. Uiteindelik val die klem in die res van die artikel op 'n Ou-Testamentiese siening van die konkrete lyf wat ander kan troos en nuwe moed gee. 


\section{DIE MENS IS 'N EENHEID}

In die $\mathrm{Ou}$ Testament is die mens 'n eenheid en alles het om die konkrete liggaam (met al sy spanning, nood, vreugde) asook sy totale leefwêreld gedraai. ' $n$ Liggaam of die totale mens is gebore, het geleef en gesterf. Daar word wel van 'n 'siel', 'hart en 'gees' gepraat, maar dit was nie aparte entiteite nie; alles het deel van die een konkrete liggaam gevorm (Preuss 1992:116-121). Dié terme het eerder op die mens se innerlike ervaringe, gevoelens, strewes, verlangens en lewenskrag gedui, en nie op iets apart binne-in die mens nie. So nou was dit met die mens se konkrete wêreld verweefd dat die woorde 'my siel' ook met 'my lewe' of 'ek' vertaal kan word (vgl Ps 6:4; 42:6-7). So word 'nefeš' in die Ou Vertaling nog met 'siel' vertaal, maar in die Nuwe Vertaling word dit tereg met 'ek' weergegee: 'so smag ek na U ... Ek dors na God' (Ps 42:3). In die sogenaamde 'heilsgeskiedenis' (die groot handelinge van God by die aartsvaders, die uittog, die woestynreis, Sinai, die intog en die Dawidsbelofte) het God konkrete liggame en totale mense gehelp, bevry en hulle in die beloofde land gelei (Westermann 1976:71-96; Stoltz 1971: 862-867; Seebass 1986:531-555; Kaiser 1998:290-318).

Mooi blyk dit byvoorbeeld uit die Moses-uittog-tradisie. Dit is ' $n$ oorweldigende teksblok en die spatsels van die uittog lê oral oor die hele $\mathrm{Ou}$ Testament versprei. Dit is interessant dat in elke uitspraak hieroor 'n konkrete groep mense die objek van God se hulp en bevryding was. Dit was 'n verlossing wat hulle totale menswees geraak het waarop hulle ook met hulle hele wese en in konkrete situasies moes geantwoord het. So moes hulle op die sabbat rus want hulle was self slawe in Egipte en hulle moes vir die vreemdelinge omgee 'want jy was self ' $n$ vreemdeling in Egipte' (Dt 5:15; 10:19). Met paasfees moes elke geslag hierdie redding so intens herdenk dat hulle as ' $t$ ware weer die lyding in Egipte en die uittog herbeleef het. In die proses moes God 'n werklikheid geword en moes hulle weer sy 'magtige dade' en 'kragtige groot dade', 'tekens' en 'wonders' ervaar het (Dt 26:7) (Von Rad 1958:177-181; Noth 1972:49; Zimmerle 1972:12-20; Schmid 1999:129-169; Rendtorff 1999:3148).

In die Ou Testament gaan dit dus om die hele mens (en nie net 'n onderafdeling nie) wat gered, bevry en gehelp moes word. Dit was ook die hele mens wat na die ander moes uitreik en die ander moes getroos het. Nadat God Eva gemaak het, het Hy 'haar na die 
mens toe' gebring. Albei was naak en Adam het haar liggaam met sy oë verken en haar andersheid raakgesien. Voor hom was 'n mens, 'n liggaam en nie " $n$ siel of gees nie. ' $n$ Mens waarin lyf, gees en siel tot een liggaam versmelt is. Een totale mens wat na ' $n$ ander uitgereik het. Twee liggame wat mekaar sou ervaar het en saam één sou word. Uit dié verbintenis het die hunkering na die ander ontstaan en daarom sou die man sy pa en ma verlaat en haar alleen 'aankleef' (Gen 2:24). In die swaar lewe van vroeg opstaan, hard werk en weinig vrug op die arbeid sien, sou haar lyf hom troos en elke dag se drag ligter maak (Kaiser 1998:287-290).

\section{DIE GEVAAR VAN 'N KOSBARE SIEL EN 'N BOSE LIGGAAM}

Vir die vroeë kerk het die mens uit siel, gees en liggaam bestaan en van dié drie was die liggaam nie die belangrikste nie. Eintlik het alles maar om die siel gewentel want God het sy beeld op die siel afgedruk (Weber, O 1957:414-415). Dit beteken egter hoegenaamd nie dat die liggaam as verwerplik of minderwaardig geag is nie. In hulle stryd teen die gnostici was so iets in elk geval onmoontlik. Volgens laasgenoemde was alle materie (soos die liggaam) boos en moes die wêreld deur askese vermy word. Alle aandag is op die siel en sy verlossing gefokus terwyl die lyflike as minderwaardig beskou is. So 'n siening was egter vir die vroeë kerk onaanvaarbaar want die liggaam se geringskatting het verreikende gevolge vir Christus se sterwe en opstanding ingehou (vgl Altaner 1951:106-109; Seeberg 1965:312-321; Bakhuizen van den Brink 1965:89-98; Drobner 1994:84-91; Rudolph 1998:86-113). Hierdie siel-gees-liggaambeskouing van die vroeë kerk het egter ook dikwels tot 'n onderwaardering van die lyflike en die seksuele gelei. Ter illustrasie van dié gedagte let ons op Augustinus en sy stryd teen die Manicheërs.

Volgens die Manicheërs was daar voor die skepping 'n groot kosmiese stryd wat in verskillende fases voltrek is: in die oertyd het lig en duisternis naasmekaar bestaan, maar toe wou die duisternis oor die lig regeer en stryd het ontstaan; aanvanklik het die lig oorwin, maar dit het mettertyd in die duisternis of die materie se kloue verstrik geraak. Alhoewel die mens geen deel hieraan gehad het nie, deel hy egter in die gevolge daarvan: binne-in elkeen woed daar 'n onophoudelike stryd tussen goed en kwaad, lig en duisternis (Poorthuis 2005:56-61). 
Die Manicheërs het gevolglik 'n pessimistiese visie op die werklikheid en op die menslike liggaam gehad. Die siel daarenteen was aan God verwant, het iets goddelik gedra en het niks met die menslike liggaam te make gehad nie. Kortom: die siel was 'n aparte entiteit wat buite die bereik van die liggaamlike was en wat nooit daardeur besoedel kon word nie. Dié siening het die Manicheërs egter anders na seks laat kyk. Omdat seks tot die liggaam beperk was en nooit die siel kon besoedel nie, was die Manicheërs meer oop vir seks en seksuele genot. Anders gestel: seksuele vreugde was iets afsonderlik en geen bedreiging vir die siel nie (Poorthuis 2005:67).

Vir Augustinus was so 'n skeiding tussen liggaam en siel onmoontlik. Seksuele genot het die siel geraak en seks is eerder met sonde verbind. Volgens hom was daar geen kosmiese stryd tussen goed en kwaad nie, was die liggaam nie vanselfsprekend sleg en die siel goddelik nie. Albei is deur God geskep en met mekaar geïntegreer (Adam 1965:267-268).

Augustinus kon dus aan seksvreugde nie 'n aparte, afsonderlike funksie toeken nie (Poorthuis 2005:68). Hy ontken nie die bestaan van die seksdrang nie, maar dit het 'n plek in die huwelik gehad waar dit die voortplanting van die menslike geslag moes dien. Eintlik moet ons dit nog sterker stel: Augustinus gee ruimte vir die seksuele, maar eintlik is die seksuele begeerte of 'concupiscentia', boos, verkeerd, sondig (Weber 1957:414-416; . Elke kind is dus in sonde ontvang en gebore en moes gedoop word sodat die spatsels van die sonde afgewas kon word. Hierdie negatiewe siening van die lyf sou die kerk nooit werklik oorwin nie en daarom sou die sensuele Hooglied altyd 'n struikelblok gebly het (Schwienhorst-Schönberger 1998a:349-351). Altyd moes die liggaam gefolter en al die bose luste geweer word. Dié siening het nog die kerk nog seks goed gedoen.

Dit beteken geensins dat Augustinus die huwelik onderwaardeer of geslagsgemeenskap afgemaak het nie. Só het sy tydgenoot en vriend, Hieronymus van Bethlehem, wel gedink. Hierdie vertaler van die Vulgaat was met 'n groot aantal weduwees bevriend en het hulle afgeraai om weer te trou. Volgens hom was die huwelik blote braaksel waarheen geen weduwee moes terugkeer nie. Dit was in elk geval ook 'n lewenstaat wat eers na die sondeval ontstaan het en daarom eerder vermy moes word (Van Geest 2005:189-190).

So het Augustinus egter nie gedink nie. Hy het die huwelik hoog geag, maar het telkens 'n uitnemender weg aangedui. Seks het sy 
plek gehad, maar albei partners moes na 'n hoër ideaal streef. En dít waarna gestreef moes word, was gemeenskap en vriendskap. Dit was 'n unieke siening vir sy tyd en daarmee wou Augustinus die huwelik weg van die seksuele en die soeke na seksuele genot stuur. Binne so 'n gemeenskaplike lewe kon twee mense leer om mekaar lief te hê, te vergewe en na mekaar toe te groei (Van Bavel 1970:23-36; Van Geest 2005:187-207). 'n Heel besondere gedagte vir sy tyd, maar dit sou ook konsekwensies vir die seksuele hê.

\section{HERONTDEKKING VAN DIE LYF}

In die westerse denke is liggaam en siel ook lank uitmekaargehou en is dit deur die kerk bestendig. Liggaam was uitgebreidheid en siel denke. Elke liggaam het tot die wêreld van dinge behoort en kon gemeet, geweeg en geanaliseer word. Elke liggaam is tot 'n objek verding en lyflike luste moes voortdurend gekontroleer en beheer word (Sartre 1966:445-460). Die sondige liggaam met al sy vleeslike begeertes was onbelangrik en moes voortdurend geskruisig word. In die proses is die mens van sy/haar liggaam vervreem. Liggaam en siel het teenoormekaargestaan en die liggaam was bloot " $n$ instrument van die 'geredde' siel of gees (vgl Foucault 1992:3-13, 249-254).

Gedurende die twintigste eeu is die lyf deur veral die Franse filosowe herontdek. 'Ek het nie 'n liggaam nie, maar is liggaam', is gesê. Vanaf my geboorte-uur is ek onherroeplik aan hierdie wêreld vasgemaak; is die band tussen my en die wêreld onverbreeklik; ontdek ek die wêreld deur my liggaam en gee ek lyflike sin daaraan (Kwant 1962:19-41). Ek is dus van die begin af ' $\mathrm{n}$ wereldling wat in die wêreld woon en volledig daarop gerig is. Uiteraard is elkeen anders in die wêreld teenwoordig en deurleef elkeen dit ook verskillend, maar die mistieke band tussen my liggaam en die wêreld is onophefbaar. Dit is so intens dat geen mens dit ooit kan deurgrond nie. Dit is net daar en sal altyd so bly (Kearney 1989:62-68).

Met my liggaam stewig in hierdie wêreld vasgeanker, reik ek na ander liggame uit. Na liggame wat kan voel en koester, vertroetel en liefhê. Elke erotiese waarneming sien die liggaam (die totale mens) van die ander eerste raak. Elke stukkie drif word op die ander se liggaam gerig. Elke lyfsbegeerte is sonder ander liggame leeg. Liggame word eers een wanneer die prikkels van die ander se lyf eroties verwerk is. En alles gebeur nie net met die sondige vlees in ' $n$ sondige wêreld los van die kosbare geredde siel nie, maar met 
wêreldlinge wat net hierdie wêreld ken en dit met hulle liggame ontdek (vgl Foucault 1990:39-54).

\section{KOESTER DAN DIE LYF}

Erens tussen 250 en $190 \mathrm{vC}$ het Prediker, soos ons die skrywer van die boek Prediker sal noem, in Jerusalem geleef en elke dag die krag van die Hellenistiese (of Griekse) kultuur en denke verinnerlik (Kaiser 2003:290). Dit was so oorweldigend dat niemand dit ooit kon ontsnap nie. En 'n mens kan dit ook in die werk van Prediker sien. Geen ander Ou-Testamentiese skrywer het soos Prediker met die impak van die Griekse denke geworstel nie. Dalk was Prediker ryk en kon hy op sy oudag terugkyk en oor die lewe besin. In sy besinning het hy egter Joods gebly, maar is fundamenteel deur Griekse idees geslyp (Hengel 1981:115-130).

So was daar in die Griekse wêreld ' $\mathrm{n}$ sterk individualisme of individualistiese gees. Hiervolgens het die private, die persoonlike dimensies van menswees meer aandag as die openbare lewe begin ontvang. Elkeen moes sélf vir hom-/haarself sorg, moes sélf na geluk en vreugde streef, en . moes sélf die kuns van selfkoestering aanleer. Die filosofie kon wel help, maar die verantwoordelikheid vir so " $n$ unieke leefstyl het by die individu sélf gelê ( $\mathrm{vgl}$ SchwienhorstSchönberger 1998b:342-344).

Vir die Grieke was dit geensins ' $n$ blote selfsugtige fokus op die self nie. Dít het die voorwaarde vir " $n$ suksesvolle en gelukkige lewe geword. Om ' $\mathrm{n}$ goeie burger te kon wees, moes 'n mens volgens Sokrates eers jouself geken het. Anders gesê: moes jy eers aandag aan jouself gegee en vir jouself gesorg het; moes jy eers jouself ontdek het. Ambisieuse jongmans wat na mag gestreef en die wêreld wou oorwin het, is aanbeveel om hulle self eers te koester. Alvorens hulle andere kon lei, moes hulle eers diep in hulleself gekyk en hulleself eers goed leer ken het. Geen goeie lewe was sonder selfkoestering moontlik nie. Rykes moes hulle grond uitverhuur sodat hulle tyd vir die self kon maak want as 'n mens nooit geleer het om vir jouself om te gee nie, was alle geld en besittings in elk geval nutteloos. Selfkoestering was deel van menswees en elkeen móés dit doen. En vir die Epikureërs kon die filosofie 'n mens help om dié kuns aan te leer en jongmans is daarom aangemoedig om onmiddellik met filosofiestudie te begin en daarmee te volhard. Niks vervang die omgee vir die self nie en daarom moes elkeen hom in die filosofie verloor het (Schwienhorst-Schönberger 1996:233-255). 
Prediker se individualisme sluit hierby aan. Lewensvreugde ontdek ' $n$ mens nie in die religieuse gemeenskap of in vaste waarhede nie, maar in selfversorging. Geluk is nie aan dinge (soos geld of belangrikheid) of aan waardes (soos die nakoming van die wet of geregtigheid) gekoppel nie, maar word in die egte ervaring van die goeie van die lewe gevind. Niks in die lewe was seker nie en daarom moes ' $n$ mens mooi na jouself kyk sodat jy elke stukkie vreugde wat die lewe jou bied, kon opslurp en voluit geniet. Of soos hy dit self stel: 'Ek het tot die insig gekom dat daar vir 'n mens niks beter is nie as om vrolik te wees en die goeie van die lewe te geniet' (Pred 3:12) (Loader 1984:41-46).

En in dié proses speel die vrou se lyf ' $n$ sleutelrol. Geniet die lewe met die vrou wat jy liefhet. Dít beveel Prediker ons! En in die $\mathrm{Ou}$ Testament speel baldige, aardse genot ' $\mathrm{n}$ sentrale rol. By die maaltyd, die ete, die drinke moes mense mekaar voluit geniet en uitbundig dankbaar vir die goeie dinge wees. By die vrou wat jy liefhet, moes jy jouself kon verloor het; moes jy elke liggaamsdeel ingedrink het; moes jy saam met die vloei van die lyf beweeg het; moes jy haar lyf se reuke ingeadem het; moes jy al die lyf se plekke van ekstase geken en geniet het. En wie so die lyf se vol genot met groot teue ingeslurp het, het die kuns van selfkoestering bemeester en het geleer om vir die totale mens te sorg (Jenni 1971:60-73; Wallis 1973:105-128; Fox 1977: 83-106; Loader 1979:32,120; 1984:121-123; Michel 1988:154-159; Spangenberg 1993:134-141; Kaiser 1995:233-253; Schwienhorst-Schönberger 1996:200-207; Schoors 2004:61,97,318-319).

\section{DIE LYF IN 'N ONAF LEWE}

Opvallend is Prediker se kritiese ingesteldheid. Hy is ' $n$ individu en vertel die wêreld soos hy dit self beleef het. Niks pas nie en daarom het hy alle waardes omgekeer. Israel se veelgeroemde 'heilsgeskiedenis' (gebeure soos die uittog en die intog) het hom min geskeel en die wysheidsleraars se oorsaak-gevolg-denke het hy heeltemal verwerp. Dit was onmoontlik om te sê dat goeie dade goeie gevolge het of dat slegte tot ellende lei. Daar was geen moraliteit in hierdie lewe nie en niks was deursigtig nie. Niemand kon God of die lewe verstaan nie en lewensin het ' $\mathrm{n}$ mens altyd maar weer ontglip. Oor en oor het hy gesê dat alles tot niks kom en dat niemand ooit seker van sukses kon wees nie. Of 'n mens nou (soos Spreuke sou sê) wys geleef het of nie, het nie eintlik saak gemaak nie. Alles was in elk 
geval tevergeefs (Hertzberg 1932:93; Fox 1986:409-427; 1998:2539).

Wat is nou die sin van die son wat vanmôre opkom en vanaand weer ondergaan? Of wat is die sin van die wind wat nou so waai en dan weer sus? Of dat riviere sonder ophou in die see loop en die see nie vol word nie. Niks maak $\sin$ in die natuur nie. En in die menswêreld is dit ook nie veel anders nie. Mense praat en praat en dit lyk nie of hulle ooit klaar gepraat kry nie. Hulle kyk en kyk sonder dat hulle ooit genoeg gesien het. Hulle hoor en hoor, maar kry nooit klaar met hoor nie (Pred 1:5-8) (Loader 1984:24-28).

Magteloos is ' $n$ mens ook aan die groot gebeure in die lewe uitgelewer. Daar is ' $\mathrm{n}$ tyd om gebore te word en daar is 'n tyd om dood te gaan en ' $n$ mens het daaroor geen beheer nie. En tussen gebore word en doodgaan gebeur soveel dinge waaroor niemand beheer het nie (Pred 3:1-9). Indien ' $n$ mens iets aanpak, weet hy nie of dit suksesvol gaan wees nie want hy is net nie in staat om die verloop van die lewe te bepaal nie (Schwienhorst-Schönberger 1996:87-100).

Hoe leef ' $n$ mens met sulke oënskynlike sinloosheid saam? Deur voluit te leef! Niemand moes vir altyd in swaarmoedigheid en pessimisme versink nie (Hertzberg 1932:114,128). Elkeen moes 'Jasê' vir die lewe. Na vele nadenke het Prediker tot die insig gekom 'dat daar vir 'n mens niks beter is nie as om vrolik te wees en die goeie van die lewe te geniet' nie. Al wat die mens nodig het, was net ' $n$ bietjie lewensgeluk. Te midde van hartseer en pyn (kortom: die sinloosheid van die lewe) moes elke mens weer in die kleingoedjies van die lewe sy vreugde begin soek het. In Prediker 3:13 word na drie dinge verwys: eet, drink, arbeid. Prediker wou hê dat ons ons lewens onder die loep moes neem; dat ons opnuut sal ontdek wat ons gelukkig maak; dat ons vreugde in ons werk en in die kleintakies van elke dag sal smaak; dat ons vreugde in die saameet met ander sal vind; dat ons by die teekamer en die koffieplek die geselligheid van mense sal geniet; dat ons opnuut in die eenvoud asook die kleindingetjies van die lewe vreugde sal put. Kortom: dat ons sal leer om onsself te koester. Dít maak die lewe mooi en sinvol (Schwienhorst-Schönberger 1996:274-332).

In elke poging om hierdie onaf lewe mooi te maak, was die vrou, die lyf onontbeerlik. In die oordaad van die liefdesgenot word die lewe se sinloosheid ver ente teruggestoot. In die intense 
liefdeservaring kiem ' $\mathrm{n}$ nuwe lewensin. In die naby-ervaring van die ander word nuwe lewensmoontlikhede ontsluit. En Prediker se klem op die onafheid was ' $n$ ander manier om lyflike genot te intensifeer. Omdat die lewe nie sinvol sluit nie, moes die lyf se genot voluit geniet word. Dít was ' $\mathrm{n}$ manier om sinloosheid te hanteer (vgl Barth 1961:383-402).

\section{DIE DOOD LÊ EN LOER}

Die dood is ' $n$ werklikheid en in ' $n$ oogwink kan dit al die lyf se vreugdes vernietig. Geluk is wel volgens Prediker moontlik, maar dit is nie iets wat ' $n$ mens kan vashou of vir ewig besit nie. Dit is iets wat elke dag toegeien, verinnerlik moet word. Veral jongmense moes altyd na dié vreugde soek en dit dan 'solank hulle leef ten volle geniet' (Pred 11:9). Hierdie 'gryp-die-dag-gedagte' was egter tipies van die Griekse wêreld en was ook aan die Jerusalemse jongmense in die derde eeu bekend. ' $n$ Jongmens moes die lewe voluit geniet het: 'Hou kommer uit jou hart en vermy wat jou liggaam kan kwaad doen' (Pred 11:10). En dan volg 'n waarskuwing: 'Ook die jeug en die jonkheid kom tot niks'. Elke stukkie jongmensvreugde word dus deur eindigheid omvou: 'Maar jy moet onthou dat die donker dae van die dood wat kom, ook baie is' (Pred 11:8). Dít maak Prediker nie noodwendig pessimisties of donker nie. Hy wou net die vreugde intensifeer. Hy wou net dat elkeen nóú, vandag nog, na lewensvreugde sal gryp en alles sal geniet want ook daaraan kom 'n einde (Schwienhorst-Schönberger 1998b:342-344).

Voordat die dood kom, word die lyf al afgetakel (Spangenberg 169-175). Pragtig vergelyk Prediker dit met 'n bouvallige huis. Daar kom 'n tyd wanneer die hande ('die wagters van die huis') begin bewe; wanneer die die bene ('die sterk manne') begin waggel; wanneer die tande ('die malers') min word en 'ophou maal'; wanneer die oë ('dié wat deur die vensters kyk') swak word; die ore ('die deure na die straat toe') dof word; die stem ('die geluid van die meul') swak word (Pred 12:3-4). En as die voëls vroegoggend begin koer, staan jy op sonder dat jy hulle eers hoor. Dit is wanneer jy vir hoogtes en baie ander dinge bang word. En terwyl die amandelboom bloei, die sprinkaan hom vol eet en die kapperkruid blom, sterf die mens. Prediker gebruik dan ' $n$ pragtige beeld: dit is soos ' $n$ silwer tou wat by ' $n$ put afbreek, soos die goue skepemmer wat breek, soos die drinkbeker wat stukkend breek en soos die wiel wat by die put inval (Pred 12:6) (Loader 1984:100). 
Teen die dood se drif en die onkeerbare gang van geboreword, leef en sterwe staan almal weerloos. En tog wou Prediker nie dat ons in ' $n$ diepe doodsdepressie moes verval nie. Sy praatjies oor die dood wou ons eerder aanspoor om elke dag opnuut die lewe te omarm en dit voluit te geniet; om op pad na die einde toe lewensmoed by die ander te vind; om deur lyflike ervaringe die angs vir die dood te verdryf; om deur die een wat ek liefhet elke dag getroos te word .

\section{DIE ANDER TROOSTER}

So het die lyf dan gekom om vir ewig by ons te bly en ons elke dag te troos en te bemoedig. Pragtig word dit ook in die verhaal van Isak en Rebekka vertel. Abraham se vrou Sara het gesterf en vir hulle seun Isak was dit moeilik. Sara was nou wel nie altyd maklik nie. Sy het Abraham by ' $n$ slavin laat slaap (Gen 16:2), gelag toe God haar van ' $n$ kind vertel (Gen 18:12) en Hagar en Ismael uit louter jaloesie verjaag (Gen 21:10), maar die band met Isak was sterk. Na haar dood was Isak ontroosbaar en daarom het Abraham 'n slaaf na ' $n$ ver land gestuur om vir sy seun ' $n$ troostertjie te loop soek (Gen 24:167). Opgewonde het Isak op hulle koms gewag en toe hy op 'n dag die kamele se stof in die verte gesien het, het hy hulle opgewonde tegemoetgeloop. In ' $n$ enkele vers word die lyf se troos aangrypend verwoord. Isak het Rebekka nooit vantevore gesien nie, maar dit het nie eintlik saak gemaak nie. Daar in sy ma se tent het Rebekka hom getroos; het die lyf van ' $n$ vrou uit ' $n$ ver land Sara se enigste kind getroos; het twee koesterende liggame mekaar besiel, bemoedig, versterk. Pragtig word die gevolg van dié lyflike ontmoeting gestel: 'en hy (Isak) het haar liefgehad'. Ewe mooi word hierdie verhaal van vrousoek en vrouvind dan ook afgesluit: 'So is Isak dan getroos ná die dood van sy moeder' (Gen 24:67 - Ou Vertaling) (Van Selms 1967:45-48; Von Rad 1970:253-255; Westermann 1985:387-392).

Dieselfde het ook met Dawid en Batseba gebeur. Hulle eerste kind is dood, maar Dawid het haar getroos. Drie dinge word van dié troos gesê: hy het 'by haar slaapkamer ingegaan', hy het 'by haar geslaap' en toe het sy swanger geword. Dawid se troos was fisies, eroties, sensueel. Met sy totale erotiese menswees (liggaam, siel, gees) het hy haar getroos en liefgehad. En die kind wat uit dié erotiese verbintenis gebore is, sou Israel se lewe nog radikaal beïnvloed. Hulle het hom 'Salomo' genoem, maar die profeet Natan het dit na 'Jedidja' verander wat 'die Here het hom lief' beteken (2 
Sam 12:24-25). Daar is so iets groots en volledig aan Dawid se lyflike troos. 'n Sterk man, 'n gelukkige vrou, 'n kind wat God liefhet. Dít is wat die lyf se troos kan doen (vgl Von Rad 1958:306317; Niehr 1998:215-216).

\section{JONK STERF IS SLEG}

As iemand jonk sou sterf sonder dat die genot van die liggaam ooit ervaar is, was dit sleg. Dít is waarom die Deuteronomiumskrywer(s) 'n spesifieke reëling hieroor gemaak het. In Deuteronomium is daar 'n radikale openheid vir die ander en sy welsyn. In alles wat gebeur, moes die ander, die broer, in ag geneem word. Wanneer 'n huis gebou word, moes daar tralies wees sodat die broer nie sal val en seerkry nie; wanneer geoes word, moes die dele langs die pad vir die honger broer gelos word; wanneer 'n slaaf ('n mede-Israeliet) sewe jaar gewerk het, moes hy in die sewende jaar weer vrygelaat word (Dt 15:12-18; 22:1-24:22). Uitdruklik word ook gesê dat 'n pasgetroude jongman nooit mag oorlog toe gaan nie. Trouens, hy moes van 'enige verpligting' vrygestel word. Geen militêre of ander verpligting mag ' $\mathrm{n}$ jonggetroude opgelê word nie. Hy moes by die huis bly en sy vrou 'gelukkig ... maak' (Dt 24:25).

Onderliggend hieraan was Deuteronomium se ideaal van die goeie lewe. Dít was nie 'n utopie nie, maar iets wat Israel híér en nóu kon ervaar. Soos wat die redding uit Egipte ' $n$ werklikheid was so kon die goeie lewe ook 'n realiteit wees. En dit was ook nie net tot enkeles beperk nie, maar almal kon die lewe se volheid geniet. En tipies van die Ou Testament was dié lewe vol daaglikse aardse gelukkies. Op die akker en in die daaglikse gang van die lewe sou dit met almal goed gaan. Daar sou ryk oeste wees en volop om van te geniet. Vrees vir misoeste en hongersnood was altyd ' $n$ werklikheid, maar Israel sou 'volop koring, wyn en olie' hê. Hulle vee sou steeds vermeerder het: 'Hy sal jou grootvee en jou kleinvee vinnig laat aanteel'. Kortom: Dit sou met Israel 'beter gaan as met al die volke' (Dt 7:12-14). Dít was die volle, goeie lewe (Von Rad 1973:9-73).

Daar was egter ' $n$ voorwaarde. Israel moes God liefhê en radikaal vir mekaar omgee. Oral en elke dag moes Israel se omgee vir mekaar gesien kon word en een so " $n$ omgee-reël was dat ' $n$ jonggetroude nie moes oorlog toe gaan nie. Hierdie ervaring van die ander se lyf en die omgee vir mekaar se liggame word elders in Deuteronomium nog skerper gestel. Wanneer mans vir ' $n$ oorlog opgeroep word, moes die leiers uitdruklik vra: 'Wie het verloof 
geraak maar is nog nie getroud nie?'. Diesulkes moes dan omdraai en teruggaan 'sodat hy nie in die oorlog omkom en 'n ander met sy verloofde trou nie' (Dt 20:7). Vir die kleingeluk van gewone mense moes elke dag voorsiening gemaak word. Met ' $n$ man en 'n vrou se binnekamervreugdes moes rekening gehou word en daarom moes ' $\mathrm{n}$ jongman tuisbly om sy vrou 'gelukkig te maak'. Telkens wanneer twee mense se liggaamsgenot tot ' $\mathrm{n}$ diepe sielsgeluk en lewensvreugde gelei het, is iets van God ervaar. Dáárom moes Israel anders oor die jong verloofde en die pasgetroude gedink het. ' $n$ Ordereëling moes dus getref word dat niemand jonk sou sterf sonder dat die lyf van die ander ooit geproe is nie. Dít was God se wil (Von Rad 1966: 11-30; 1958:218-230; Otto 1998:1-84; 1999a:1-100; 1999b:693-696; 2000:234-273; 2002a:92-276; 2002b:276-313).

\section{ONPAS LIGGAME TROOS NIE}

Nie alle lywe troos nie en daarom paat Prediker van die vrou 'wat jy liefhet'. Vir lywe om mekaar te troos, moet liefdesbande hulle aanmekaarknoop. As dít nie gebeur nie, kom alles inderdaad tot niks nie. Aangrypend vertel ' $n$ wysheidsleraar in die Spreukeboek van 'n lyf wat nooit genot kan bied nie en niemand kan troos nie. In dié betrokke Spreukegedeelte word die wysheidsleraar se 'werk' pragtig geillustreer. Hy het die gewone lewe bestudeer sodat hy kon vasstel watter soort gedrag geluk en watter soort smart meebring. En die gevolg van sy skerp kyk op die lewe was 'n waarskuwing teen liggame wat nie kan troos nie. Dié moes vermy word (vgl Snijders 1984:7-20).

Hy vertel hoe hy een skemeraand 'by my huis, by die tralievenster' uitkyk (Spr 7:6). Daar is ' $\mathrm{n}$ klomp mense, maar 'veral een onverstandige jongman' val hom op (Spr 7:7). Hy stap in die rigting van ' $\mathrm{n}$ sekere vrou se huis, maar sy het hom reeds gesien en hom tegemoetgeloop ( $\mathrm{Spr}$ 7:10). Opvallend is die manier waarop die vrou haar rol speel. Sy is 'reg' aangetrek en haar klere verraai haar aard. Sy loop uitlokkend en uitdagend en sy praat luidrugtig sodat die jongman haar kan hoor. Die wysheidsleraar ken diesulkes en sê dat haar huis te nou en sy frustreerd geword het. Haar man was weg en toe die luste haar oorweldig het, het sy na iemand gaan soek. In 'die strate' en 'op die stadspleine' het sy rondgedwaal en op die straathoeke gestaan en rondloer (Spr 7:9-12). En dan skielik verskyn 'n mooi jongman. Sy gryp hom, gee hom 'n soen en nooi hom na haar huis toe. Sy sê dan vinnig 'n klomp onsinnighede. Sy vertel dat sy die hele dag al na hom gesoek het, dat sy geoffer het en nou ' $n$ 
partner soek om die offervleis klaar te eet; dat sy ' $n$ mooi deken het om hom te wys; dat hy nie hoef bang te wees nie want haar man was weg. Na vele omweë sê sy uiteindelik wat sy wil hê. Sy vra dat hulle moet drink van die liefde, hulle liefdeslus uitleef, mekaar se liggame volledig geniet, fisies en geestelik inmekaar opgaan (Spr 7:18) (McKane 1977:331-341).

En tog het dit nie gewerk nie want niks het die liggame aanmekaargebind nie. Liefdelose lywe kan mekaar tog nie troos of gelukkig maak nie. By diesulkes kan niemand tevredenheid, rustigheid, vrede vind nie. Sulke liggame dompel ' $n$ mens net in die allergrootste ellende. Wie by diesulkes slaap, is 'soos 'n bees op pad slagpale toe' en soos ' 'n voël wat reg in 'n net in vlieg' (Spr 7:22-23) (vgl Kaiser 1993:263-299).

\section{SLOTWOORD}

Sonder " $n$ lyf se warmte gaan dit met niemand goed nie. Dit is net die lyf wat kan warmmaak en troosgee. Dit is net die lyf wat na " $n$ nag se lang genot nuwe krag en hoop kan gee. En wanneer dit gebeur, is dit net genade. Niemand tref dit egter ooit volmaak met hierdie wêreld nie en daarom kan liggame soms bymekaar verbyleef. Ons moet dus altyd lyflik oopbly na mekaar toe en op mekaar se erotiese prikkels antwoord. Of soos die hy-figuur in Hooglied dit pragtig sê: 'Liefstetjie, hoe wondermooi is jy nie en hoe volmaak die genot van jou liefde tog nie', en die sy-figuur dan daarop antwoord: 'Ek behoort aan my liefling wat na my smag en verlang. Kom, my liefling, kom ons gaan loop in die veld en oornag in die dorp' (vgl Hgl 7:6,10,11 - 'Die Boodskap'). En wanneer twee liggame mekaar so omvou, ervaar gewone mense ook God se troos.

\section{Literatuurverwysings}

Adam, A 1965. Lehrbuch der Dogmengeschichte. Gütersloh: Gerd Mohn.

Altaner, B 1951. Patrologie. Freiburg: Verlag Herder.

Bakhuizen van den Brink, J N 1965. Handboek der kerkgeschiedenis. Den Haag: Bert Bakker.

Barth, K 1961. Die Kirchliche Dogmatik III/3. Zürich: EVZ-Verlag.

Drobner, H R 1994. Lehrbuch der Patrologie. Freiburg: Herder.

Foucault, M 1990. The care of the self. London: Penguin Books Ltd.

-, 1992. The use of pleasure. London: Penguin Books Ltd.

Fox, M V 1977. Frame narrative and composition in the Book of Qohelet. HUCA 48, 83-106. 
-, 1986. The meaning of 'hebel' for Qohelet. JBL 105, 409-427.

-, 1998. Time in Qohelet's catalogue of time. JNSL 24, 25-39.

Hengel, M 1974. Judaism and Hellenism. London: SCM Press.

-, 1981. Judaism and Hellenism. London: SCM Press.

Hertzberg, H W 1932. Der Prediger (Qohelet). Leipzig: Scholl.

Jenni, E 1971. 'hb lieben. THAT 1, 60-73.

Kaiser, O 1993. Der Gott des Alten Testaments. Wesen und Wirken 1. Göttingen: Vandenhoeck \& Rurprecht.

-, 1995. Beiträge zur Kohelet-Forschung. Eine Nachlese. ThR 60, 1-31, 233253.

-, 1998. Der Gott des Alten Testaments. Wesen und Wirken 2. Göttingen: Vandenhoeck \& Rurprecht.

-, 2003. Der Gott des Alten Testaments. Wesen und Wirken 3. Göttingen: Vandenhoeck \& Rurprecht.

Kearney, R 1986. Modern movements in European philosophy. Manchester: Manchester University Press.

Kwant, R C 1962. De fenomenologie van Merlau Ponty. Utrecht: Aula-Boeken. Preuss, H D 1992. Theologie des Alten Testaments, 2. Köln: Verlag W. Kohlhammer.

Loader, J A 1979. Polar structures in the Book of Qohelet. Berlin: De Gruyter.

-, 1984. Prediker: Een praktische bijbelverklaring. Kampen: Kok.

McKane, W 1977. Proverbs. London: SCM Press.

Michel, D 1988. Qohelet. Darmstadt: Wissenschaftliche Buchgesellschaft.

Niehr, H 1998. Die Samuelbücher, in Zenger, E (red), Einleitung in das Alte Testament, 210-216. Stuttgart: W. Kohlhammer.

Noth, M 1972. A history of Pentateuchal traditions. Englewood Cliffs: Prentice-Hall Inc.

Otto, E 1998. Die Ursprünge der Bundestheologie im Alten Testament und im Alten Orient. ZAR 4, 1-84.

-, 1999a. Das Deuteronomium. Berlin: Walter de Gruyter.

-, 1999b. Deuteronomium. $R G G$ 4/II, 693-696.

-, 2000. Das Deuteronomium in Pentateuch und Hexateuch. Tubingen: J. C. B. Mohr (Paul Siebeck).

-, 2002a. Gottes Recht als Menschenrecht. Rechts- und literaturhistorische Studien zum Deuteronomium. Wiesbaden: Harrasowitz Verlag. 
-, 2002b. Max Webers Studien des Antiken Judentums. Historische Grundlegung einer Theorie der Moderne. Tübingen: J. C. B. Mohr (Paul Siebeck).

Poorthuis, M 2005. Mani, Augustinus en de Kabbala over eten en sex: een vergelijking, in Van Geest, P \& Van Oort, J (reds) 2005. Augustiana Neerlandica, 55-71. Leuven: Peeters.

Rendtorff, R 1999. Theologie des Alten Testaments, 1. Neukirchen: Neukirchener Verlag.

Rudolph, R 1998. Gnosis. The nature and history of Gnosticism. Edinburgh: T\&T Clark.

Sartre, J P 1966. Being and nothingness. New York: Washington Square Press.

Schmid, K 1999. Erzväter und Exodus. Neukirchen: Neukirchener Verlag.

Schoors, A 2004. The preacher sought to find pleasing words. Leuven: Uitgeverij Peeters.

Schwienhorst-Schönberger, L 1996. Nicht im Menschen Gründet das Glück. Freiburg: Verlag Herder.

-, 1998a. Das Hohelied, in Zenger, E (red), Einleitung in das Alte Testament, 344-351. Stuttgart: W. Kohlhammer.

-, 1998b. Das Buch Kohelet, in Zenger, E (red), Einleitung in das Alte Testament, 336-344. Stuttgart: W. Kohlhammer.

Seebass, H 1986. næfæš. TWAT 5,531-555. Stuttgart: Verlag W. Kohlhammer.

Seeberg, R 1965. Lehrbuch der Dogmengeschichte. Darmstadt: WBG.

Snijders, L A 1984. Spreuken. Kampen: J H Kok.

Spangenberg, I J J 1993. Die boek Prediker. Kaapstad: NG Kerk-Uitgewers.

Stoltz, F 1971. lēb, Herz. THAT 1, 862-867. München: Chr. Kaiser Verlag.

Van Geest, P 2005. Gemeenschap, ontrouw, vergeving en onthouding, in Van Geest, P \& Van Oort, J (reds) 2005. Augustiana Neerlandica, 187-207. Leuven: Peeters.

Van Selms, A 1967. Genesis 2. Nijkerk: Callenbach.

Von Rad, G 1958. Theologie des Alten Testament 1. München: Chr Kaiser Verlag.

-, 1966. Deuteronomy. A commentary. London: SCM Press.

-, 1970. Genesis. London: SCM Press.

-, 1973. Das Gottesvolk im Deuteronomium, in Gesammelte Studien zum Alten Testament 2, 9-73. München: Chr Kaiser Verlag.

Wallis, G 1973.'hb. TWAT 1, 105-128. 
Weber, O 1957. Anthropologie, III. Theologiegeschichtlich. $R G G$ Bd. 1, S. 414-420. Tübingen: J.C.B. Mohr (Paul Siebeck).

Westermann, C 1976. nøefcěs, Seele. THAT 2, 71-96. München: Chr. Kaiser Verlag.

-, 1985. Genesis 12-36. Minneapolis: Augsburg Publishing House.

Zimmerli, W 1972. Grundriss der Alttestamentliche Theologie. Stuttgart: Verlag W. Kohlhammer. 